\title{
Correction to: Graphic Analysis Between Teaching and Research. Mario Ridolfi Unbuilt
}

\author{
Virginia Lorello and Francesco Maggio
}

\section{Correction to: \\ Chapter "Graphic Analysis Between Teaching and Research. Mario Ridolfi Unbuilt" \\ in: E. Castaño Perea and E. Echeverría Valiente (eds.), Architectural Draughtsmanship, https://doi.org/10.1007/978-3-319-58856-8_39}

In the original version of the book, the following belated corrections have been incorporated in the chapter "Graphic Analysis Between Teaching and Research. Mario Ridolfi Unbuilt": The author "Virginia Lorello" is to be added as the first author of the chapter, and the author "Vincenza Garofalo" is to be deleted. The correction chapter and the book have been updated with the change. 